\title{
The Socio-Cultural Significance of the Kakube Festival of the Dagara of Nandom Traditional Area in Ghana
}

\author{
Conrad-J.Wuleka Kuuder and Raymond Adongo \\ Dept. of Ecotourism and Environmental Management \\ University for Development Studies \\ Nyankpala Campus-Ghana \\ Email ${ }^{1}$ : ckuuder@yahoo.co.uk \\ Email²:ogbaus@yahoo.com \\ and \\ Joe Abanga \\ Dept. of Hospitality and Tourism Management \\ University of Cape Coast \\ Cape Coast-Ghana \\ Email: joeabanga@yahoo.com \\ DOI: http://dx.doi.org/10.4314/gjds.vgi2.6
}

\begin{abstract}
The advent of western civilization has had a downturn on many important cultural practices of the people in Sub-Saharan Africa. Understandably so, a form of reawakening in recent times has led to people going back to their roots to rediscover what their forebears 'executed' with passion. This paper generally explores the importance of local events such as the festivals which bring people together to celebrate a common heritage. It finally narrowed in on the people of Nandom who trace their roots to a common ancestor and as such make feverish attempts aimed at ensuring that an annual affair (Kakube) comes into fruition. Data was sourced from key personalities in the community making use of both simple random and purposive sampling techniques and further employing data collection methods such as administration of questionnaire, in-depth interviews (IDI) including personal observation and participation. In all, 250 people responded to the questionnaire. The analysis revealed that the people of the area benefited socially, culturally, economically, politically, religiously and developmentally hence their adherence to this heritage. The paper recommends that the Nandom Traditional Council,
\end{abstract}


the Lawra District Assembly, the local business community, the Ghana Tourism Authority and civil society organisations should help in its promotion both nationally and internationally.

KEYWORDS: Kakube festival, tourism, cultural heritage, tradition, dimension,

\section{Introduction}

Local culture is regarded today as an important tourism resource (Hunter and Green, 1995) and festivals are prominent "components" in the culture of many societies and are inevitable in the tourism literature for they form a part of the heritage of many nations. Today, as people wake up somewhere or go to bed elsewhere, within certain timeframes of the year, in cities, towns and villages, people will be celebrating a festival or festivity of some kind.

In defining a festival especially within an African context, Busia (1962) says they are seasonal occasions when offerings and prayers are made to ancestors and also involve elaborate ceremonies of rites of purification, drumming, dancing, singing, with the recital of tribal history and reaffirmation of values, the tribe shares and cherishes.

Festivals vary and are celebrated for various reasons and purposes. For instance, in India, a major festival in the Hindu calendar is Diwali or the festival of lights celebrated to welcome Lakshmi, the goddess of wealth and prosperity and the light that empowers us to commit ourselves to good deeds; that which brings us closer to divinity (Diwali, 2010). Again, in the streets of Rio de Janeiro (Brazil), a popular festival known as Mardi Gras (Fat Tuesday) is held. It brings people from all walks of life to mingle with natives to eat, drink and entertain themselves by way of parades, dancing and carnivals hence making it socially inclined. However, popular Catholic practices are also associated with celebrations of it before the fasting and religious obligations associated with the penitential season of Lent. This also gives a clue that it has some religious connotations as well and the festival is a rich source of tourism related income to the country (Rosenberg, 2004). The Mashona of Malawi, thank their ancestral spirits (Mhondoro) through an annual festival celebrated in honour of them, rendering the festival spiritual and/or worship inclined (Latham, 1979). Fertility of the land, adequate rains and a good harvest are believed to come from the spiritual bliss, hence making Mhondoro the true owners of the land (Ranger, 1979; Lan, 1989; Spierenburg, 2005; Uusihakala, 2008).

In Ghana, festivals are common events in all the fifty-two calendar weeks of a year and run through the nook and cranny of the country. Festivals form a rich portion of our cultural heritage; their celebrations are encouraged by the Centre for National Culture (CNC) and many of them get corporate support during festive times. A notable company in this 'business' is the Ghana Breweries Limited (GBL), brewers of star beer and in recent time, Mobile Telecommunication giants also sponsor some festivals and use the occasion to advertise and sell their products. 
Some popular festivals in the country include the Hogbestosto of the Anlo of the Volta Region, the Aboakyer (deer hunt) festival of the Effutu of Winneba, Edina Burunya celebrated in Elmina to usher in the New Year and the Homowo of the Ga which is celebrated to signify an end to hunger in memory the suffering of their ancestors, are notable festivals of southern Ghana. The Samanpid Festival of the Kusasi of Bawku, the Kobine Festival of the people of Lawra, the Fiok of Sandema (Builsa tribe) and recent time the Bong Ngo Festival of Jirapa, most of which are agriculture-related are notable festivals in Northern Ghana.

This study centres on the Kakube festival of the Dagara in the Nandom Traditional Area of the Upper West Region of Ghana. It is celebrated annually in the last week-end of November.

Despite the negative effects of western civilization on many a cultural practice in Africa, festivals all over the continent and particularly in Ghana continue to play important roles in relation to religion, politics, economics, development, culture and historical. Above all, festive help to place the locality and people on the tourism map of the nation. Based on the above, one wonders if the same can be said of the Kakube festival in the Nandom Traditional Area. Hence, this is what this study seeks to unearth.

\section{Festivals and Development-A Review}

Festivals are said to have historical, religious, cultural, social, economic, as well as political and developmental dimensions (Gursay, Kim and Uysal, 2004). The background literature examined some selected festivals in relation to these dimensions.

\section{Historical Dimensions}

Generally, festivals have a lot of history behind their celebrations. For many who trace their roots through a common ancestry, their forebears must have gone through some 'turbulent circumstances' in their existence as a community and through some forms of endurance were able to overcome. Hence festive occasions are instituted in remembrance of such circumstances or events and the values handed over from generation to generation culminating in these annual ceremonies. On the historical significance of celebrating festivals, Albanese (1992) writing about the Passover celebrated by the Jews pointed out that it was an important religious event but was later attached a historical importance. Accordingly, the Passover was originally celebrated to mark the sewing of seed and the renewal of clan and kinship ties but as time passed, new interpretations were added. The Jews now regard the Passover as a historical event (feast) to relive their exodus from Egypt and the birth of the Jewish nation. They interpreted it to mean they had passed over from slavery to freedom and even of more significance to them was the issue of the angel of death slaying the Egyptians but passed over the first born among the infant sons of Israel. During the Jewish festival of Passover, which is hitherto celebrated in 
Israel, tribal history is recounted to the youth so that they know the circumstances which necessitated their movement to their present home.

Writing in the same light, Bame (1991) 'touches' on the Hogbestosto among the Anlo in Eweland (Ghana) and recounts how they narrate a legend at the festival pertaining to the exodus of the tribe from Ngotsie. Accordingly, Agokoli, the cruel king of Ngotsie put them to forced labour asking them to knead clay with their feet from mud in which he had mixed thorns and to make ropes out of clay. Through the guidance of Akolasofoe, the wise elder, they constantly poured water at the foot of the high walls of the town until it became soft enough for them to dig through with sticks and one night they broke through the wall walking backwards with their faces to the city so that their footprints might deceive the people about their direction. Today the festival is celebrated annually which is interpreted as 'the exodus of the tribe'. This history is recounted yearly at the festival with some drama performed to demonstrate how they departed from Ngotsie. Hence, festivals have historical developmental dimensions, as they serve as constant recounts of history and sustain the oral traditions of the people through generations.

\section{Religious Dimensions}

Religiosity has been part and parcel of human existence. For the African, Mbiti (1969) notes that he or she is notoriously and incurably religious. Hence, an element of religion is found in every facet of African life with festivals as no exception. With regard to this, Meyerowitz (1958) deliberates on the rituals performed during the Afahyia festival of the Akan at Kuntumso in Ghana and the significance they attach to such rituals. She says, on sacred Monday (Fo-Dwoo-kese) people gather in the courtyard of Taa Kuntun's sanctuary (local deity) and from there, a mass procession forms to mark the beginning of the ritual and as they walk down the well site they chant the praises of the deity. On arrival at the wells, the prophetic high priest makes libation and makes a small offering of eggs and mashed yam at the well site. The significance the Akan of Kuntumso attached to this ritual is that they all anticipate entering the New Year with 'happy returns'.

Goody (1972) in shedding light on the Bagre festivities among the LoDagaa in Northern Ghana (specifically the town of Birifo) talks of how the people offer sacrifices through the 'gods' (ngmime), the ancestors (Kpiin) and the earth goddess (tengan) during the Bagre celebrations but the ultimate recipient of the sacrifice being the Supreme Being (Naangmin). He further explains that outside a LoDagaa house are a number of shrines made from sticks, stones and clay and these he termed tiib (medicine shrines). All these shrines, he pointed out, are consulted during the festivities especially for protection.

With regard to religious issues in festivals expressed by Meyerowitz, (1958) and Goody (1972), it is worthy of note that, after the necessary sacrifices to their deities, people go about their daily activities with zeal feeling protected by the powers of the supernatural. 


\section{Cultural Dimensions}

The celebration of culture which is the major attracting force is the main element which brings people from all walks of life (Ghosh, 2000) including tourists to a destination or to participate in an event. In this light, Briggs (1998) brings to the fore, the fact that Oguaa Fetu Afahye is an important event on the Fante calendar which draws lots of visitors. Afahye means the adorning of the new native clothes. Briggs places emphasis on the beautiful dresses, costumes and other regalia worn by the local chiefs and Asafo companies. According to Briggs, chiefs lead processions through the streets of Cape Coast (Ghana) during the festival and describe it as very appealing.

Bame (1991) also dilates on the Argungu fishing and cultural festival in Nigeria and places emphasis on its cultural aspect. Unlike Briggs, however, Bame focuses on folk singing and dancing instead of dressing. Bame stated that during the Argungu, artistes are not only from Sokoto and other Nigerian states but similar performers are invited from neighbouring Niger Republic every year. He adds that the guest group and the local artistes such as Hadjia Lolo and her Salla Group and the Angele dancers would, in preparation for this festival, compose new songs, improve their singing and polish their dancing styles and perform briskly on the day of the competition. Festivals are therefore occasions when the best aspects of culture are displayed to attract visitors, hence development.

\section{Social Dimensions}

Festivals draw people from all walks of life. This portrays the social factor that is very appreciated by many in Ghana. In many Ghanaian societies, an "invisible register" of attendance is marked by families and community members at such social gatherings. People from the locality who are domiciled in other parts of the country are obliged to attend such occasions as shows of concern to family, clan and community while they in return will be willing to help in time of need or grieve. Hence, festival occasions are times most people take some days off their busy work schedules to return to their roots to reunite with folks.

Field (1961) in noting the Kpawulu Kplekemo (the immense decent of the gods), a ceremony in the Homowo festivities among the Ga mentions that at this function hundreds of 'bush' people are present. Field says early in the day they begin to arrive and stay for more than a week and that the social solidarity made manifest at this time is more than impressive. He went on to mention that oneness with their ancestors is the keynote of this great gathering together. Everyone's keen delight - is to visit the family town and be united with the ancestral home. Wives who have married men of other towns or other quarters of the same town leave their husbands and re-join their own people. Field finally concluded saying formerly all the people made a ceremony of their entry by clearing the bush along the paths in order to broaden them. 
Powers (1995) writing in line with the assertion of Field (1961) noted that festivals bring members from all parts of the community together voluntarily to celebrate in heritage. This asset of development is ignited in the wake of festivals

\section{Economic Dimensions}

Festivals ignite communities financially by virtue of the large crowds they draw with many potential and actual buyers. Powers (1995) describes a festival as a quasi-business activity and says the success of a festival is measured by its ability to attract visitors/tourists to cover its costs and to maintain sufficient local support to keep it staffed. Mention is made of Quebec's ice carnival which begun in 1954 "to energise a stagnant economy is accordingly now the city's third largest industry and generates revenue of \$30 million a year". Explaining further, Powers alludes to the festival posing a major economic impact on the community especially its hospitality industry. Hospitality industry managers are often seen to be prominent sponsors and backers of such events because they reap from visitors "spending on food, lodging, souvenirs, gasoline, public transportation and the like." Shifting focus to the Pan-Hellenic festivals at Olympia and Athens, Price (1999) slightly differed in his opinion from the situation in Quebec as highlighted by Powers (1995). The Pan-Hellenic festivals, according to Price, took the form of games and the economic (financial) gains attracted lots of competitors. Victors in games in Olympia won only a crown and subsequently a pension from their own city whereas victors at Athens won substantial sums. He specifies that in the fourth century, first prize in lyre competition was a crown of gold leaf worth 1000 drachmas and 500 silver drachmas at a time when a skilled labourer's daily wage was one drachma. The financial gains which were very attractive at the time drew lots of competitors who spent lots of efforts in training for these events. Many spectators were also attracted across the country to witness these festivals. Hence, the economic gains obtained by participants during festivals serves as a stimulus for development.

\section{Political Dimensions}

In contemporary times, festivals play a role in the political arena of a nation. These serve as platforms for the elected and the electorate or the ruler and the ruled to interact and deliberate on issues. Traditional authorities do 'seize' these festival occasions to re-assert their authority over their subjects and to carefully plan actions for their communities (Dubnick, 2004 cited in Bonye, 2006).

On the political dimensions of festivals, Bame (1991) again expresses his view concerning the farming ritual festival of the people of Congo in which the chief and his wife play key roles in ritual activities. He further reveals that the indigenes renew their loyalty and pay homage to their leaders. The traditional political role according to him has taken on a national outlook in the emerging African states nowadays in that, governments of the day use the opportunity for exchange of goodwill between chiefs whose people are celebrating the festival and the government of the day. 


\section{Developmental Dimensions}

Festivals serve as forums for initiating community projects and again are the appropriate grounds for contributing seed money to these projects. Public education on health issues, sanitation, sustainable agricultural practices are best executed on no other grounds than festival occasions. In line with the above, Hood (1973) in writing about the developmental roles of festivals dwells on the use of human intelligence to take practical steps for improving 'adverse conditions' and survival. Hood says in Egypt when the Nile River begins to recede in volume, the people worked hard to preserve water for the season of drought. Commenting further, she said the people practiced irrigation farming by digging canals, dykes and wells using great water wheels to direct the flow of water to their farms to support all year round agriculture. The people of Egypt believed they could control nature through rituals including the use of human intelligence to improve natural conditions. Festivals were therefore celebrated to mark their ability to use both rituals and their intelligence to control the forces of nature for their upkeep and well-being hence leading to sustainable development. She then drew the conclusion that many of the Egyptian festivals were centered on the Nile and the purpose was to control the level of the river and bring prosperity to the land. This element of sustainable development and enhancing the quality of the human and natural environment is fostered by the celebration of festivals (Getz, 1991).

In Ghana and particularly in the northern communities, Bonye (ibid) noted that even though sufficient existing evidence indicates that there are adequate policies and programmes that create the enabling environment to ensure that local people participate and articulate their views in the development discourse of their communities, the reality is that, these policies and programmes are not responsive enough to the needs and demands of the people especially in poverty alleviation efforts. Yet some indigenous institutions such as traditional festivals are pertinent to ensuring effective community organization, communication and accountability systems in their societies.

\section{The Kakube Festival-A Brief Historical Perspective}

Historically, Kakube has been celebrated by the people of Nandom until 1933 when the first Christian Missionaries arrived with their 'New God'. The arrival of the missionaries negatively impacted on the celebration of the festivity as converts preferred to celebrate Christmas both of which were celebrated about the same time. According to legend, Mr. Aricadio Terkemuureh, a scholar of the traditional area and a cultural enthusiast sold the idea to the Nandom Naa who then invited him to re-echo the idea in a forum with his divisional chiefs. Mr. Terkemuureh was then given the nod to organise the occasion. He got a group of opinion leaders from the traditional area and after a brainstorming session, the name Kakube was found to be appropriate. Committees were formed comprising accommodation, finance, food and drinks, transport and grounds while appeals were made to divisional chiefs and philanthropic organizations to contribute 
either in cash or kind. In November, 1989, the festival was launched. The Kakube festival centres on farming and before the festivity begins, it is the Kakube daa (local alcoholic beverage) brewed from treated malt which is used in pouring libation to kick start it. The significance of this ritual is that until the Kakube daa is brewed and used in libation prayers to the ancestors, no farmer is allowed to sell new grain in the market. After the successful launch of the festival, Kakube went national in 1991, whereby state functionaries were invited.

Nandom is in the Upper West Region of Ghana, about 12okm further north of the Regional Capital, Wa. It is within the Administrative District of Lawra and is 3okm north of the district capital. The border town of Hamile is $16 \mathrm{~km}$ further north of Nandom. The town is bordered to the east by the Black Volta River and to the north and west is the newly created district capital of Lambussie-Karni. Within the southern sector of it are the towns of Lawra and Jirapa, respectively. The Nandom Traditional Area is made up of seventy three (73) communities (See the Lawra DHMT Annual Report, 2002).

The major economic activity in the area is farming (cultivation, rearing and small scale fishing). Others also engage in small-scale commercial ventures or businesses (trading). Many of the women engage in 'pito' brewing (a local alcoholic beverage) through which they earn income.

\section{Methodology}

For the gathering of relevant data, our respondents included assemblymen, traditional rulers, farmers and teachers. The respondents were basically Dagara, who are natives of Nandom and are currently working and residing in the traditional area. Respondents were both literates and non-literates. Priority was given to those who had lived in the area for long (5 years or more). Assemblymen were a resource group, since they live with the people and are the 'mouth piece' of the communities as they liaise between the community and the district assembly on development issues. Traditional rulers (chiefs) were another 'rich resource' because they play key roles in the celebration of the Kakube festival. Farmers were also a group considered very useful for this study since the festival is agriculturerelated. They eventually proved their worth as 'good material' for the study. Finally, some teachers within the traditional area were contacted as opinion leaders as some served on festival committees.

The simple random sampling method and some non-probability methods (specifically snowball) were employed. Chances were given to anyone who was in a position to deliver the information and qualified to participate as prescribed by set guidelines. It was ensured that the respondents fell within the sample frame (assemblymen, traditional rulers, farmers and teachers). Nandom has a total population of 46, 298 (Lawra DHMT Annual Report, 2002) out of which two hundred and fifty (250) people were selected by employing the Fisher et al (1998) formulae for sample size calculation. As the population of the area 
which stands at 46, 298 is greater than 10,000, the sample size would be calculated by the formula as follows:

$$
\begin{aligned}
& n_{f=} \frac{n}{1+\frac{n}{N}} \text {, where } \\
& n_{f}=\text { the desired sample size ( when population is less than 10,000), } \\
& n=\text { the desired sample size (when population is greater than 10,000), } \\
& N=\text { the estimate of the population size } \\
& \text { But to determine } \mathrm{n}_{\mathrm{f}} \mathrm{n} \text { would have to be calculated. According Fisher et } \\
& \text { al, when the population is greater than 10,000 the sample size is } \\
& \text { determined by: } \\
& \mathrm{n}=\underline{\mathrm{Z}}^{\underline{2}} \underline{\underline{ } q} \\
& d^{2} \\
& \text { Where: } \\
& n=\text { the desired sample size (when the population is greater than 10,000) } \\
& z=\text { the standard normal deviation, usually set at } 1.96 \text { (or more simply 2.0) which } \\
& \text { corresponds to } 95 \text { percent confidence level } \\
& p=\text { the proportion in the target population estimated to have particular } \\
& \text { characteristics } \\
& q=1.0-p \\
& d=\text { degree of accuracy desired, usually set at } 0.05 \text { or occasionally at } 0.02
\end{aligned}
$$

Assuming the target population that is aware of the festive occasion in the destination area is $80 \%$, (this community possesses attractions obtained through a house to house survey) the $\mathrm{z}$ statistic being 1.96 and desired accuracy at 0.05 percent, then the sample size is:

$$
\begin{aligned}
& \mathrm{n}=\frac{(1.96)^{2} \frac{2}{(0.80)(0.20)}}{0.05^{2}} \\
& \mathrm{n}=245
\end{aligned}
$$

In this regard, the sample size calculated was 245 respondents but since the number of questionnaires distributed was more (275), it was realized that at the time of retrieval, 250 of these were noted to be usable. 
With regard to educational institutions, there were 56 schools in the traditional area comprising 30 primary schools and 26 Junior High Schools. Two (2) teachers from each of the 56 schools were randomly picked through the ballot method whereby two $\underline{\text { Yes }}$ and four № ballot papers were given to all in each school. Those with the Yes were given the chance to respond and 112 respondents fell in this category. With the traditional rulers, since they are the custodians of the culture of the area, any of them who agreed to respond was automatically given the chance. The snowball method was used to track them. After meeting a particular chief, he would recommend another whom he thought would also be helpful with information. With the assemblymen, Nandom was demarcated into 25 electoral areas and 18 of them were purposively contacted in their electoral areas and they responded. The multi-stage sampling was used to select the farmers. The 73 communities were zoned into four groups comprising zone A-18, zone B-18, zone $\mathrm{C}-18$ and zone $\mathrm{D}-19$. The simple random method was employed to select 22 farmers from each zone making 88 farmers. Those who took part comprised 18 assemblymen, 32 traditional rulers, 88 farmers and 112 teachers making up the 250 respondents (sample size).

The instruments for the collection of data were based on questionnaires, scheduled interviews and personal observations. A single questionnaire was designed for all groups of respondents. A five likert scale response module was developed with options for them to explain their choice of response. On the whole, two hundred and seventy-five (275) questionnaires were distributed and 250 were retrieved. Questionnaires were given to respondents who could read and write. A time frame of two weeks was given after which the completed questionnaires were retrieved. The non-literates were guided, questions were read out to them in local the dialect (Dagara) and their responses interpreted and recorded on the questionnaire.

Among the 250 people who responded, 25\% were between the ages of 20-29, Close to $16 \%$ were within the age bracket of 30-39, about $13 \%$ were within $40-49 y e a r s, 12 \%$ within $50-59$ and $34 \%$ of them were 60 and above. The principal reason for engaging majority of the senior citizens $(60+)$ was because of their 'wealth of knowledge' concerning the festival and culture of the traditional area. On level of educational attainment, 10\% had no formal education, $15 \%$ had primary education, and another $15 \%$ had Junior High School and Secondary education whilst $60 \%$ were educated to the tertiary level. The high rate of literates engaged was due to the involvement of teachers many of whom, as said earlier, served on festival committees. With regard to religious affiliation, $31 \%$ of respondents were Christians, $19 \%$ were Muslims and 50\% were traditional worshippers. On length of stay in the locality, $6 \%$ of respondents had lived in the locality for 5years plus, $24 \%$ had lived therein for 10years plus, $25 \%$ had been there for the past 2oyears and above and majority (46\%) had been "bread and buttered" in the traditional area for zoyears and more. More chances were opened to people who had lived in the traditional area for longer periods because such citizens will have a 'reservoir' of knowledge to draw from. 


\section{Results and Discussions}

According to responses gathered from the field, the significance of the Kakube festival is seen in the following spheres:

\section{Religious}

With regard to the religious importance of the festival, $72 \%$ (see Table 1 first item under \{i\}) strongly agreed that indigenes communed with their local deity at the timaal per (local shrine).In an interview with one of the elders in the community, he explained the meaning of Kakube as follows:

Kakube literally means "the remnants of grain collected after drying the guinea corn harvest on the traditional mud roof (garu). When this dried staple is put in the barn, the remnants on the garu are swept which will definitely contain some pebbles/stones. These remnants are gathered, sorted and treated into malt and finally the malt used in the brewing of the Kakube daa" popularly known as pito (an alcoholic beverage).

At the local shrine, indigenes pour libation with the Kakube daa and the significance of this ritual is that until this liquor is offered in libation prayers at the local shrine, farmers are prohibited to sell 'new' guinea corn in the market. Preceding the libation prayer is the offer of sacrifices of a fowl, goat and sheep, the making of pledges and asking for the blessings of the ancestral gods for the ensuing year. In this same vein, the opinion expressed by Smith (1974) is also highlighted in talking about Tenjin festival which is held annually in July in the city of Osaka (Japan). Smith stated that at the shrine known as Kitano Temmangu, petitioners ask for good health, protection from misfortune and prosperity. These are the ideals sought after at times of sacrificing to the local deities in Nandom. Residents therefore leave the local shrine filled with hope, enthusiasm and good expectations for the next farming season. The tengansob (owner of the land/earth priest) is again called upon to make libation before all gathered to grease the occasion at the durbar ground. This religious parlance discussed here is in consonance with Goody's (1972) finding regarding the Birifo people during their Bagre festivities. Additionally, at the durbar ground, on the watch of all gathered a Catholic priest and an Imam are called upon to offer prayers before the start of proceedings. Hence, all respondents affirmed that some forms of Christian and Muslim prayers were offered.

\section{Social}

With reference to the re-unification with kith and kin (Crompton, 1979), all responses were in the affirmative. It was considered a time for meeting and making new friends. Close to $88 \%$ of the respondents (that is $58 \%+30 \%$ ) agreed that the festival was an occasion for general merry making and socialization in consonance with the deliberations of the social dimensions of festivals as posited by Opoku (1970: 5) said: 
I believe festivals are important today, more than they were before. People now go to take part in these festivals because they want to return to their place of birth and meet the old friends and relatives again and join them in merry making. At a time when the need for money is forcing Ghanaians to leave their towns and villages to look for work elsewhere, these festivals offer the best opportunity to go back to our heritage, renew old ties and draw inspirations for the future.

However, a further $4 \%$ disagreed while $6 \%$ strongly disagreed (see Table 1 , fourth item under $\{\mathrm{ii}\}$ ) with the assertion claiming that though the day might start in a joyous mood for many, it turned up being sad for others because lots of bicycle and motorbike accidents were recorded during the period culminating in various forms and levels of hospitalization.

\begin{tabular}{|c|c|c|c|c|c|c|}
\hline & $\begin{array}{l}\text { Strongly } \\
\text { agree (\%) }\end{array}$ & $\begin{array}{l}\text { Agree } \\
(\%)\end{array}$ & $\begin{array}{l}\text { No } \\
\text { Opinion } \\
(\%)\end{array}$ & $\begin{array}{l}\text { Disagree } \\
(\%)\end{array}$ & $\begin{array}{l}\text { Strongly } \\
\text { disagree } \\
(\%)\end{array}$ & $\begin{array}{l}\text { TOTAL } \\
(\%) \\
(\mathbf{N}=\mathbf{2 5 0})\end{array}$ \\
\hline \multicolumn{7}{|l|}{$\begin{array}{l}\text { \{i\} Religious } \\
\text { importance }\end{array}$} \\
\hline $\begin{array}{l}\text { Indigenes commune } \\
\text { with their local deity }\end{array}$ & 72 & 27 & 1 & o & 0 & 100 \\
\hline $\begin{array}{l}\text { People offer Christian } \\
\text { and Moslem prayers }\end{array}$ & 88 & 12 & o & 0 & 0 & 100 \\
\hline \multicolumn{7}{|l|}{ \{ii\} Social Importance } \\
\hline $\begin{array}{l}\text { Re-uniting with kid } \\
\text { and kin }\end{array}$ & 89 & 11 & 0 & 0 & 0 & 100 \\
\hline $\begin{array}{l}\text { Occasion for making } \\
\text { new friends }\end{array}$ & 75 & 15 & O & 5 & 5 & 100 \\
\hline $\begin{array}{l}\text { Opportunity to } \\
\text { fraternize with } \\
\text { guest(tourists) }\end{array}$ & 66 & 20 & 10 & 4 & 0 & 100 \\
\hline $\begin{array}{l}\text { There is general Merry- } \\
\text { making }\end{array}$ & 58 & 30 & 0 & 4 & 6 & 100 \\
\hline $\begin{array}{l}\text { Renewal of friendship } \\
\text { ties }\end{array}$ & 55 & 15 & 3 & 7 & 20 & 100 \\
\hline
\end{tabular}




\begin{tabular}{|c|c|c|c|c|c|c|}
\hline & $\begin{array}{l}\text { Strongly } \\
\text { agree (\%) }\end{array}$ & $\begin{array}{l}\text { Agree } \\
(\%)\end{array}$ & $\begin{array}{l}\text { No } \\
\text { Opinion } \\
(\%)\end{array}$ & $\begin{array}{l}\text { Disagree } \\
(\%)\end{array}$ & $\begin{array}{l}\text { Strongly } \\
\text { disagree } \\
(\%)\end{array}$ & $\begin{array}{l}\text { TOTAL } \\
(\%) \\
(\mathbf{N}=\mathbf{2 5 0})\end{array}$ \\
\hline \multicolumn{7}{|l|}{$\begin{array}{l}\text { \{iii\} Cultural } \\
\text { Importance }\end{array}$} \\
\hline $\begin{array}{l}\text { Showcasing of local } \\
\text { cuisine }\end{array}$ & 65 & 35 & 0 & 0 & o & 100 \\
\hline $\begin{array}{l}\text { Display of traditional/ } \\
\text { indigenous attire }\end{array}$ & 60 & 20 & 0 & 15 & 5 & 100 \\
\hline Display of royal regalia & 80 & 20 & $\mathrm{o}$ & o & o & 100 \\
\hline $\begin{array}{l}\text { Exhibition of native } \\
\text { dancing }\end{array}$ & 95 & 5 & 0 & o & 0 & 100 \\
\hline $\begin{array}{l}\text { Display of indigenous } \\
\text { musical instruments }\end{array}$ & 90 & 10 & 0 & 0 & 0 & 100 \\
\hline $\begin{array}{l}\text { Local artiste compose } \\
\text { new songs on topical } \\
\text { issues to sing to the } \\
\text { audience }\end{array}$ & 57 & 43 & 0 & 0 & 0 & 100 \\
\hline $\begin{array}{l}\text { Showcasing of } \\
\text { craftworks }\end{array}$ & 56 & 44 & 0 & 0 & 0 & 100 \\
\hline $\begin{array}{l}\text { Farmers exhibit native } \\
\text { staple foods }\end{array}$ & 66 & 30 & 4 & 0 & 0 & 100 \\
\hline \multicolumn{7}{|l|}{$\begin{array}{l}\{\text { iv }\} \text { Economic } \\
\text { Importance }\end{array}$} \\
\hline $\begin{array}{l}\text { Buying and selling is } \\
\text { brisk }\end{array}$ & 82 & 18 & 0 & 0 & 0 & 100 \\
\hline $\begin{array}{l}\text { Accommodation } \\
\text { facilities are fully } \\
\text { booked }\end{array}$ & 73 & 17 & 10 & 0 & 0 & 100 \\
\hline $\begin{array}{l}\text { Award of cash prizes to } \\
\text { winning dance troupes }\end{array}$ & 70 & 30 & 0 & 0 & 0 & 100 \\
\hline $\begin{array}{l}\{\mathrm{v}\} \text { Historical } \\
\text { Importance }\end{array}$ & & & & & & \\
\hline
\end{tabular}




\begin{tabular}{|c|c|c|c|c|c|c|}
\hline & $\begin{array}{l}\text { Strongly } \\
\text { agree (\%) }\end{array}$ & $\begin{array}{l}\text { Agree } \\
(\%)\end{array}$ & $\begin{array}{l}\text { No } \\
\text { Opinion } \\
(\%)\end{array}$ & $\begin{array}{l}\text { Disagree } \\
(\%)\end{array}$ & $\begin{array}{l}\text { Strongly } \\
\text { disagree } \\
(\%)\end{array}$ & $\begin{array}{l}\text { TOTAL } \\
(\%) \\
(\mathbf{N}=\mathbf{2 5 0})\end{array}$ \\
\hline $\begin{array}{l}\text { Recital of festival } \\
\text { history }\end{array}$ & 60 & 30 & 10 & 0 & 0 & 100 \\
\hline $\begin{array}{l}\text { Learning of traditions/ } \\
\text { values by the youth }\end{array}$ & 62 & 12 & 12 & 14 & 0 & 100 \\
\hline \multicolumn{7}{|l|}{$\begin{array}{l}\{\text { vi\} Political } \\
\text { Importance }\end{array}$} \\
\hline $\begin{array}{l}\text { Paramount chief sits in } \\
\text { state to receive homage }\end{array}$ & 74 & 26 & 0 & 0 & 0 & 100 \\
\hline $\begin{array}{l}\text { Presence of other } \\
\text { invited chiefs }\end{array}$ & 78 & 22 & 0 & 0 & 0 & 100 \\
\hline $\begin{array}{l}\text { Attendance/talks by } \\
\text { government officials }\end{array}$ & 82 & 18 & o & O & 0 & 100 \\
\hline \multicolumn{7}{|l|}{$\begin{array}{l}\text { \{vii\} Developmental } \\
\text { importance }\end{array}$} \\
\hline $\begin{array}{l}\text { Boosting the town's } \\
\text { image }\end{array}$ & 55 & 13 & 3 & 29 & 0 & 100 \\
\hline $\begin{array}{l}\text { Public education on } \\
\text { hazards of bushfire }\end{array}$ & 70 & 23 & 7 & 0 & 0 & 100 \\
\hline $\begin{array}{l}\text { Award of prizes to } \\
\text { deserving communities } \\
\text { in their fight against } \\
\text { bushfire }\end{array}$ & 72 & 18 & 10 & 0 & 0 & 100 \\
\hline $\begin{array}{l}\text { Launching of } \\
\text { educational } \\
\text { endowment fund }\end{array}$ & 45 & 25 & 20 & 8 & 2 & 100 \\
\hline $\begin{array}{l}\text { Crowning of Miss } \\
\text { Kakube }\end{array}$ & 62 & 13 & 25 & O & 0 & 100 \\
\hline
\end{tabular}

Table 1: Perceived benefits derived from Kakube festival,

Source: Field survey, 2009 
On visits by tourists to the festival, most respondents (86\%) affirmed they did see tourists at the festival while a fair number of respondents further stated that some tourists even participate in the local dance (see plate 1) and some locales do fraternize with them.

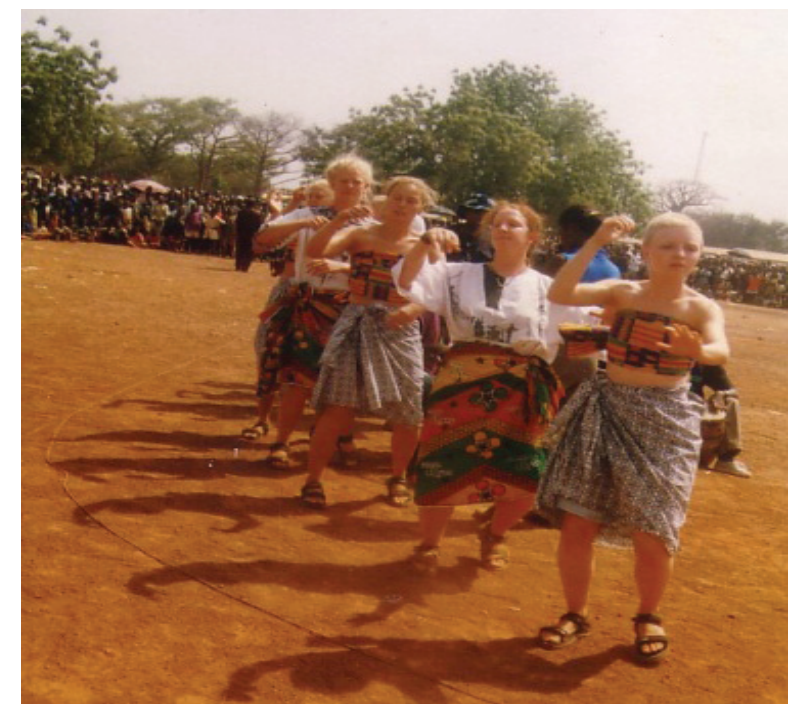

Plate 1: Some tourists performing 'bewaa'(dance) during Kakube

Majority of respondents (55\%) and (15\%) agreed that the festival was an occasion for the renewal of friendship ties often accompanied with sitting together to eat and drink. This is probably in line with the assertion of Hood (1973) who cites Daphni in Greece where a wine festival is held and any amount of seventy different wines can be drunk upon payment of an entrance fee. She also gives Munich as another example where a beer festival has been held every year since 1938.

According to Hood, an average of 3,500,000 litres of beer is drunk and 300,000 barbecued chickens, 700,000 pairs of sausages and a few tonnes of fried fish are eaten. She then came to a conclusion that at such festivals, it is most unlikely those participating will have many if any thoughts of religion but basically to make merry.

A fair bit of responses (27\%), on the contrary, disagreed (refer to Table 1, fifth item under \{ii\}) and indicated some people had their relationships marred during such occasions citing reasons like high intake of alcohol leading to misbehaviour such as fighting, raging of insults hence souring friendship ties built for years.

\section{Cultural}

Regarding the cultural import of festivals, again all respondents agreed the Kakube was an occasion to showcase local cuisine, display royal regalia, exhibit native dances (see plate 2) including crafts and display musical instruments (see plate 3 ). This is in line with the 
assertion that festivals reflect the rich diversity of history and culture of tribal life in the various traditional groupings in Ghana (Bonye, 2006).



Plate 2: A parade of dance troupes getting poised to perform during Kakube

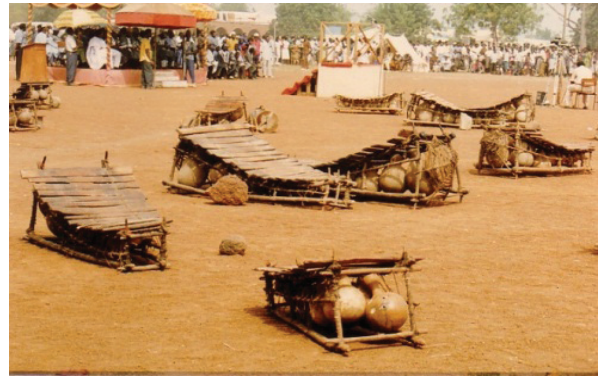

Plate 3: Display of musical instruments (gyile) during Kakube

It is also an occasion for farmers to exhibit the produce of the area for the rest of the country to see. These according to respondents were the elements which attract tourists to the locality. This is in line with the assertion of Ghosh (2000) who posits that the culture of an area was the predominant element which attracted tourism and further noted that if every area of the earth were blatantly the same, there would not be the need to travel.

However, whereas $80 \%$ agreed to the assertion of showcasing indigenous dressing, $20 \%$ disagreed noting that with regard to the display of traditional attire (dressing) by natives, it was mostly the traditional rulers who were conspicuously seen in indigenous wear (see plate 4). Most of the youth and according to their estimation close to $80 \%$ were seen dressed in modes akin to the western world. In their view, the earlier something is done about this the better for the upliftment of the cultural heritage in the area. 




\section{Plate 4: Paramount Chief of Nandom, Naa Dr. Puobe Chiir VII, in red smock, and some of his sub-chiefs in traditional attire performing the bine dance}

\section{Economic}

From the responses, it is evident that the Kakube is of great economic importance to the people of the traditional area. The climax of the festival is usually on a Sunday, which is also the local market day for the community. The marketing activities are usually relocated to the durbar ground area where the festival is celebrated. People from the rank and file of the region and indeed even outside the region do come to display their wares. There is brisk business during the occasion as attested by the $82 \%$ of respondents who strongly agreed with the assertion hence affirming the statement of Fosu (1999), who expounded on the economic relevance of festivals. He opined that it brings most of the citizens together to contribute financially and this helps to initiate development projects. Fosu further added that visitors who also came to witness the festival contributed economically to the progress of the locality through their spending in the area. Getz (1991) also expatiated on the economic impact of events seeing them as catalyst in rejuvenating local economies. Nandom is imbued with quite a number of accommodation facilities. Responses from the survey and personal cross checks indicate that these facilities are booked in advance by guests (both foreign and domestic), sometimes a week before the occasion starts. About $70 \%$ of respondents stated that some cash prizes were awarded the competing dance troupes. Most respondents claimed they were not in a position to know the exact amount but suggested it should be reviewed upwards annually to enable the teams compete briskly so as to keep the culture of the area alive. 


\section{Historical}

The history behind the festival was recited to all and sundry including guests who attended. It is most expected that the youth of the locality would acquire some knowledge with regard to their area and in this regard $62 \%$ strongly agreed that indeed the youth really learnt some aspects of their traditions such as in music and dance, xylophone performances, local craft works and the reasons behind certain rituals. This is probably in line with the assertion of Bame (1991) who indicated that the history of the Hogbestosto was recounted to the youth of Anlo in the Volta Region during the period of the festival. During the Passover, history is also recounted to the youth pertaining to how the angel of death passed over the houses of the first born sons of the Israelites and the slaying the sons of the Egyptians (Albanese, 1992). A fair number (14\%) of responses however disagreed claiming most of the young men and women rather preferred to be in popular drinking spots, food joints while others roamed around and so were rarely within the confines of the durbar ground to observe and listen to what was going on.

\section{Political}

Most respondents (74\%) with regard to the political significance of the festival strongly affirmed that (see Table 1 first item under \{vi\}) the festival was an occasion for the paramount chief to sit in state and receive homage from his sub-chiefs and subjects. This confirms Bame's (1991) assertion on the political role of chiefs during festive occasions. According to them ( $78 \%$ of respondents) other chiefs were also invited and it was the norm to make a prominent paramount chief from within the region to be chairman of the occasion while $82 \%$ also noted the presence of government officials in line with the assertion that festivals are occasions for duty bearers/politicians to visit such communities celebrating these festivals to solicit their support and also to explain policies to them. The head of government or his representatives attend and use the occasion to solicit political support especially when elections are approaching while the people also make known their needs to the powers that-be. Again, governments have issued policies and programmes over the years aimed at creating the enabling environment through which festivals can be used as platforms for dialogue with duty bearers (GPRS, 2003) while communities have also often used these festival occasions to dialogue with policy makers and politicians for development projects (Nukunya, 2003 cited in Bonye, 2006).

\section{Developmental}

Developmentally, respondents (55\%) strongly agreed that the Kakube boosted the image of Nandom because it tags the town on the festival map of the country, drawing people from all walks of life to participate including foreigners (tourists) to have a feel of the heritage of the town. It was also used as a platform to campaign against bushfire (70\% strongly agreed to this). 
In an interview with the paramount chief of Nandom regarding to the reason for his passionate fight against bushfire, he had this to say:

I had an opportunity to visit the northern Nigerian State of Kano where I saw with my own eyes the devastating effects of the Sahara Desert and as I traced the position/location of Nandom in terms of latitudinal location with Kano, I realized the difference was not vast. Hence I therefore did not want my area (paramouncy) to experience what I witnessed. This is the main reason behind my passionate anti-bushfire campaign. Through my own initiatives, prizes were awarded to deserving divisional chiefs (during the festival) who led their communities in the fight against bushfire

Indeed, $72 \%$ of respondents strongly agreed to the assertion that prizes were given to deserving chiefs in their fight against bushfire.

In contemporary circles, there is the annual crowning of Miss Kakube at the town's community centre on the final day of the festival (62\% strongly affirmed this). However, with regard to boosting the town's image, $29 \%$ of respondents were of the view that the occasion was also marred by sexual promiscuity, fighting/quarrelling, drunkenness, theft and other irresponsible behaviours. They explained that guests who fall victim of theft in particular would leave the place with ill feelings rather the good memories intended.

\section{Conclusion}

The paper found out that the Kakube festival was a major heritage handed down to them by their ancestors. Hence, it was pertinent for protecting their heritage by way of continuity for future generations to learn about it and also contribute their in bit keeping the culture of the area alive. It also came to the limelight that people who hail from the locality seized the festive occasion to travel home to see the old folks and meet other relations and in their own little way contribute their quota to the development of the area in the form of financial contributions to family or communal projects. The festival and for that matter the town has been placed on the tourism map of Ghana as both foreign and domestic tourists come to celebrate with the chiefs and people of Nandom. The interest of the visitor lies in the fact that the Dagara have a unique dance and a musical instrument (xylophone) which indeed appeals greatly to lots of people outside the traditional area.

\section{Recommendations}

D It is envisaged that the celebration of Kakube must be kept alive at all cost for it is a major heritage and this therefore calls for effective planning and promotion for maximum participation. 
$>$ Sponsorship must be sourced broadly taking into consideration the local business community, the Ghana Tourism Authority, corporate organizations, Non-governmental organisations and from some averagely well-to-do natives.

> As a matter of urgency, the Lawra District Assembly must make frantic efforts at developing some of the potential tourist attractions in the Nandom Traditional Area. This will afford visitors the opportunity to use the festival occasion to tour these sites.

$>$ As suggested by respondents, the current phenomenon of the composition of the festival committees, majority of who are drawn from the palace should seize. The festival committees must be broad based comprising of representatives from all villages in the traditional area. This will bring in the real essence of a "common heritage" and these committees must then be urged to be transparent in their disbursement of material and financial donations. Elaborate income and expenditure records must be prepared for scrutiny for this will repose confidence in people and organizations to donate towards the festival effort.

\section{References}

Albanese, C. L. (1992). American Religions and Religion. California: Wadsworth Publishing Company.

Bame, K. N. (1991). Profiles in African Traditional Popular Culture. New York: Clear Type Press Inc.

Bonye, S. (2006). "The Role of Traditional Festivals as Fora for Action Planning and Social Accountability Discourses." The Harmattan Series, Occasional Paper No. 2. Graduate School, UDS-Ghana.

Briggs, P. (1998). Guide to Ghana. UK: Bradt Publications.

Busia, K. A. (1962). The Challenge of Africa. New York: Frederich A. Praeger Publishers.

Crompton, J. L. (1979). "Motivations for pleasure vacations." Annals of Tourism Research, 6(4), 408 - 424 Diwali. (2010). Encyclopædia Britannica. Encyclopaedia Britannica Deluxe Edition. Chicago: Encyclopædia Britannica.

Dubnick, M. (2003). Clarifying accountability: An Ethical Theory Framework. Rutgers University Network.

Field, M. J. (1961). Religion and Medicine of the Ga People. London: Oxford University Press. 
Fisher, A.A., Laing, J.E., Stoeckel, J.E., and Townsend, J.W. (1998). Handbook for Family Planning Operations Research Design. New York: Population Council.

Fosu, K. A. A. (1999). Festivals in Ghana. Accra: Me Alberto (GH) Ltd.

Getz, D. (1991). Festivals, Special Events and Tourism. New York: Van Nostrand Reinhold

Ghana National Development Planning Commission (2003). Ghana Poverty Reduction Strategy 2003-2005 (GPRS I). Accra: NDPC

Ghosh, B. (2000). Tourism and Travel Management. New Delhi: Vikas Publishing, PVT LTD.

Goody, J. (1972). The Myth of the Bagre. Oxford: Clarendon Press.

Gursay, D, Kim, K. \& Uysal, M. (2004). "Perceived Impacts of Festivals and Special Events by Organizers: An Extension and Validation.” Tourism Management. 25(2), $171-181$

Hood, G. (1973). Festivals. Exeter: A. Wheaton and Company.

Hunter, C. \& Howard, G. (1995). Tourism and the Environment.Padstow: PJ Press (Padstow) Ltd.

Idowu, E. B. (1975). African Traditional Religion. London: SCM Press Limited.

Lan, D. (1989). Guns and Rain, Guerrillas and Spirit Mediums in Zimbabwe. Berkeley: University of California Press.

Latham, C.J.K. (1979). The Social Organization of the Mashona, Part III. The Southern Rhodesia Native Affairs Department. Annual for 1979.

Lawra District Health Management Team (2002). "Annual Report submitted to Upper West Regional Health Directorate," Wa, Ghana, 24tth November 2002.

Mbiti, J. S. (1969). African Religions and Philosophy. London and Edinburgh: Morrison and Gibb Ltd.

Meyerowitz, E. L. R. (1958). The Akan of Ghana, Their Ancient Beliefs. London: W. C: Faber and Faber Ltd,

Nukunya, $\mathbf{K}$ (2003). Tradition and change, An introduction to sociology. Accra: Ghana Universities Press.

Opoku, A. A. (1970). Festivals of Ghana. Accra: Ghana Publishing Corporation.

Powers, T. (1995). Introduction to Management in the Hospitality Industry. New York: John Wiley and Sons Inc.

Price, S. (1999). Religions of the Ancient Greeks. Cambridge: Cambridge University Press. 
Ranger, T (1979). Revolt in Southern Rhodesia 1896-7: A study in African Resistance. London: Heinemann.

Rosenberg, M.T. (2004). The Handy Geography Answer Book, New York: Barnes \& Nobles.

Smith, R. J. (1974). Ancestor Worship in Contemporary Japan. California: Standard University Press.

Spierenburg, M. (2005). "Spirits and Land Reforms in Dande, Northern Zimbabwe." Journal of Religion in Africa35(2): 197-229

Uusihakala, K. (2008). Memory Meanders, Place, Home and Commemoration in an Ex = Rhodesian Diaspora Community. Academic dissertation, University of Helsinki, Finland, Helsinki University Press. 